\title{
Promotional effect of microRNA-194 on breast cancer cells via targeting F-box/WD repeat-containing protein 7
}

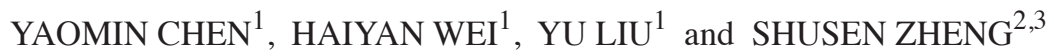 \\ ${ }^{1}$ Department of Breast Surgery; ${ }^{2}$ Zhejiang University, School of Medicine, The First Affiliated Hospital, Ministry of \\ Public Health, Key Laboratory Combined Multiorgan Transplant, Collaborative Innovation Center for Diagnosis \\ and Treatment of Infectious Diseases; ${ }^{3}$ Zhejiang University, School of Medicine, The First Affiliated Hospital, \\ The Department of Hepatobiliary Surgery, Hangzhou, Zhejiang 310003, P.R. China
}

Received January 17, 2016; Accepted January 26, 2017

DOI: $10.3892 / 01.2018 .7842$

\begin{abstract}
Breast cancer is the most common type of malignant cancer in females. An increasing number of studies have revealed that microRNAs (miR), which belong to a class of small non-coding RNAs, serve an important role in a number of human cancer subtypes. In the present study, the role of miR-194 in breast cancer cells and its underlying mechanisms were investigated. The results demonstrated that the serum levels of miR-194 were significantly higher in patients of the poorly differentiated and well-differentiated groups, compared with in healthy adults. Additionally, the serum level of miR-194 was significantly higher in the poorly differentiated group compared with in the well-differentiated group. In order to further investigate the role of miR-194 in breast cancer cells, the present study transfected two breast cancer cell lines, MCF-7 and MDA-MB-231, with an empty vector (control), miR-194 (overexpression), antagomiR-194 (inhibitor, functional knock down) or antagomiR-194 and miR-194. An MTT assay was performed in order to detect the proliferation of breast cancer cells in the various groups. The results revealed that the overexpression of miR-194 significantly accelerated cell proliferation, whereas the inhibition of miR-194 significantly decelerated the proliferation of MCF-7 and MDA-MB-231 cells. Furthermore, the expression levels of cyclin D and cyclin E were significantly upregulated in miR-194 overexpressing cells, and the expression levels of cyclin D and cyclin E were significantly downregulated in miR-194 inhibited cells, as compared with in control cells. No significant change was observed in the
\end{abstract}

Correspondence to: Dr Shusen Zheng, Zhejiang University, School of Medicine, The First Affiliated Hospital, Ministry of Public Health, Key Laboratory Combined Multiorgan Transplant, Collaborative Innovation Center for Diagnosis and Treatment of Infectious Diseases, 79 Qingchun Road, Hangzhou, Zhejiang 310003, P.R. China E-mail: shusenzheng@zju.edu.cn

Key words: breast cancer, proliferation, microRNA, F-box/WD repeat-containing protein 7 level of proliferation of cells co-transfected with miR-194 and antagomiR-194, compared with in the control cells. According to the hypothesis suggesting possible target genes of miR-194, the present study proposed that F-box/WD repeat-containing protein $7(F b x w-7)$ may be a direct target of miR-194, which was confirmed by a luciferase reporter assay. The present study suggested that miR-194 expression promoted the proliferation of breast cancer cells by targeting $F b x w-7$, and may serve as a biomarker and a novel target for breast cancer therapy.

\section{Introduction}

Breast cancer is the most commonly occurring type of cancer in females, and excessive proliferation of tumor cells is an important factor affecting the prognosis of breast cancer $(1,2)$. In recent years, an increasing number of studies have demonstrated that microRNAs (miRNA/miR) are involved in the diagnosis, treatment and prognosis of breast cancer (3-5), including a large-scale scientific investigation into molecular biological markers for monitoring the tumor progression, diagnosis or therapy (6,7). Previous studies have revealed that miR-194 is highly expressed in numerous types of human breast cancer and radiation-induced breast cancer $(8,9)$; however, the underlying mechanisms require further investigation.

F-box/WD repeat-containing protein 7 ( $F b x w-7)$, is a tumor suppressor that has been demonstrated to regulate several oncoproteins (10) including, cyclin D, cyclin E (11-13), c-Myc $(14,15)$, aurora kinase A (16), Notch (17-20) and the proto-oncogene c-Jun $(21,22)$ c-Jun, an extensively-studied member of the JUN family, has been associated with cell proliferation, tumor cell survival and apoptosis (23). Therefore, it is important to investigate the $F b x w$-7-associated signaling pathways involved in the proliferation of breast cancer. Previous studies have focused on the signal factors for the expression of $\mathrm{Fbxw}-7$ prior to and following its transcription $(24,25)$. It has previously been revealed that the Fbxw-7 gene may be suppressed due to methylation of its promoter region (26). In addition, it has been demonstrated that miR-223 serves a critical role in human gastric cancer by targeting Fbxw-7 (27). These studies suggest that Fbxw-7 is important in human types of cancer for its interactions with alternative genes. 
The present study demonstrated that the serum expression levels of miR-194 were significantly higher in patients with breast cancer compared with in healthy adults. Additionally, the overexpression of miR-194 significantly inhibited the proliferation of breast cancer cells by directly targeting the 3'-untranslated region (3'-UTR) of Fbxw-7 and by regulating the cell cycle. Overall, the results of the present study demonstrated that miR-194 expression has a significant impact on the progression of breast cancer and may be a potential therapeutic target for breast cancer.

\section{Materials and methods}

Patients and samples. Blood samples were obtained by EDTA vacutainer blood collection tubes (BD Biosciences, Franklin Lakes, NJ, USA) and immediately stored at $-80^{\circ} \mathrm{C}$ from 43 patients with breast cancer (aged 18-80 years) at the First Affiliated Hospital of Zhejiang University (Hangzhou, China) between April 2013 and April 2015. The samples were immediately stored at $-80^{\circ} \mathrm{C}$ until use. All of the patients were female and $>18$ years old. A total of 26 of the patients were identified to have well differentiated breast cancer (grade I-II) and 17 had poorly differentiated breast cancer (grade III). A total of 20 healthy adults were recruited from the First Affiliated Hospital of Zhejiang University to participate in the study as the control group. The Ethics Committee of The First Affiliated Hospital of Zhejiang University approved the present study. Written informed consent was obtained from all participants included in the study.

Cell lines. Two breast cancer cell lines, MCF-7 and MDA-MB-231, were obtained from the American Type Culture Collection (Manassas, VA, USA). They were cultured in Dulbecco's modified Eagle's medium (DMEM) with high glucose (Gibco; Thermo Fisher Scientific, Inc., Waltham, MA, USA), supplemented with $10 \%$ fetal bovine serum (FBS) and $100 \mathrm{U} / \mathrm{ml}$ penicillin and $100 \mu \mathrm{g} / \mathrm{ml}$ streptomycin, at $37^{\circ} \mathrm{C}$ in $5 \% \mathrm{CO}_{2}$.

Transfection of miRNA or the inhibitor. Breast cancer cells were seeded in a 24 -well plate with a density of $4 \times 10^{4}$ cells/well and cultured for $24 \mathrm{~h}$ at $37^{\circ} \mathrm{C}$ prior to transfection. Subsequently, the cells were starved for $1 \mathrm{~h}$ at $37^{\circ} \mathrm{C}$ using FBS-free medium without antibiotics. Transfection with the negative control oligonucleotides (NC mimic), miR-194, antagomiR-194 or miR-194/antagomiR-194 was performed using Lipofectamine ${ }^{\circledR} 2000$ reagent (Invitrogen; Thermo Fisher Scientific, Inc.), according to the manufacturer's instructions. Briefly, $0.5 \mu \mathrm{g}$ miRNA was diluted with $100 \mu \mathrm{l}$ Opti-MEM (Thermo Fisher Scientific, Inc.) without FBS, which was mixed with $1.25 \mu$ l Lipofectamine ${ }^{\circledR}$ LTX reagent (Invitrogen; Thermo Fisher Scientific, Inc.). The mixture (containing the transfection reagents) was incubated for $25 \mathrm{~min}$ at room temperature, and then added to wells containing cells and incubated at room temperature for $4 \mathrm{~h}$. Following $48 \mathrm{~h}$ transfection at $37^{\circ} \mathrm{C}$, the cells from the various groups were seeded $\left(1 \times 10^{4}\right.$ cells $\left./ \mathrm{ml}\right)$ onto 96-well plates in triplicate, and then cultured at $37^{\circ} \mathrm{C}$ for $24 \mathrm{~h}$.

RNA isolation and reverse transcription-polymerase chain reaction $(R T-P C R)$. Total RNA was isolated from breast cancer cell lines using TRIzol ${ }^{\circledR}$ (Invitrogen; Thermo Fisher Scientific, Inc.), chloroform, isopropanol and ethanol, following the manufacturer's instructions. The isolated RNA, including miRNA, was dissolved in $30 \mu \mathrm{l}$ diethyl pyrocarbonate-treated (high temperature sterilization at $121^{\circ} \mathrm{C}$ for $20 \mathrm{~min}$ ) water. In order to detect the serum levels of miR-194, the total RNA was transcribed into cDNA using the miScript II RT kit (Qiagen GmbH, Hilden, Germany). cDNA was synthesized with the Prime-Script RT reagent kit (Takara Bio Inc., Otsu, Japan) from $500 \mathrm{ng}$ of total RNA. RT-PCR was performed in triplicate using Fast SYBR ${ }^{\circledR}$ Green Master Mix (Thermo Fisher Scientific, Inc.), according to the manufacturer instructions of the ABI Prism ${ }^{\circledR} 7900$ HT Sequence Detection System (Applied Biosystems; Thermo Fisher Scientific, Inc.). The primer pairs for miR-194 were as follows: Forward, 5'-CTAAGCTTAGTG GGCATGGGACACTCT-3' and reverse, 5'-CTGAATTCA CCTGCCTCTCCTTCTTCGT-3'. U6 was used as an internal control. The primers for U6 were as follows: Forward, 5'-CTC GCTTCGGCAGCACA-3' and reverse, 5'-AACGCTTCACGA ATTTGCGT-3'. The PCR reaction conditions were as follows: $95^{\circ} \mathrm{C}$ for $5 \mathrm{~min}$ heating; 40 cycles of $95^{\circ} \mathrm{C}$ for $10 \mathrm{sec} ; 59^{\circ} \mathrm{C}$ for $40 \mathrm{sec}$; and $72^{\circ} \mathrm{C}$ for $1 \mathrm{~min}$ for application. The $2^{-\Delta \Delta \mathrm{Cq}}$ method was used for quantification of the relative expression levels of miR-194 in the samples of various groups (28).

Western blot analysis. Total protein was extracted from breast cancer cell lines following a 48-h transfection using the ProteoPrep ${ }^{\circledR}$ Total Extraction Sample kit (Sigma-Aldrich; Merck Millipore, Darmstadt, Germany). The protein concentrations were evaluated using an enhanced Bicinchoninic Acid assay kit (Beyotime Institute of Biotechnology, Haimen, China), according to the manufacturer's instructions. Equal concentrations of the extracted proteins and the 5X SDS-PAGE sample loading buffer were then heated at $95^{\circ} \mathrm{C}$ for $10 \mathrm{~min}$. Equal quantities of the protein samples (25 $\mu \mathrm{g} /$ lane) were loaded onto the gel for $10 \%$ SDS-PAGE. Subsequently, the proteins were transferred to a polyvinylidene fluoride membrane. Following washing with TBS and Tween-20, the membranes were blocked with 5\% nonfat milk and $1 \%$ Tween-20 in TBS at room temperature for $2 \mathrm{~h}$, and subsequently incubated with the following primary antibodies: Anti-Fbxw-7 (cat. no. ab74054; 1:1,000), anti-cyclin D (cat. no. ab7958; 1:500), anti-cyclin E (cat. no. ab7958; 1:500) and $\beta$-actin (cat. no. ab8227; 1:5,000). All primary antibodies were purchased from Abcam (Cambridge, UK). Following washing with TBST three times, the membranes were incubated with the corresponding anti-rabbit IgG (cat. no. A0545; 1:20; Sigma-Aldrich; Merck KGaA) conjugated with horseradish peroxidase (OriGene Technologies, Inc., Rockville, MD, USA) for $1.5 \mathrm{~h}$ at room temperature. The membranes were visualized using an enhanced chemiluminescence kit (Pierce; Thermo Fisher Scientific, Inc.).

MTT assay. Breast cancer cells $\left(1 \times 10^{4}\right.$ cells/well) in the various groups were seeded into a 96-well plate with $100 \mu \mathrm{l}$ of medium/well. The cells were plated in quintuplicate each day. Following culture at $37^{\circ} \mathrm{C}$ for $24 \mathrm{~h}, 20 \mu \mathrm{l}$ MTT solution ( $5 \mathrm{mg} / \mathrm{ml}$; Invitrogen; Thermo Fisher Scientific, Inc.) was added to each well and incubated at $37^{\circ} \mathrm{C}$ for $4 \mathrm{~h}$. Subsequently, the supernatant in each well was removed and $150 \mu$ l dimethyl 
sulfoxide was added in order to dissolve the formazan crystals. The absorbance wavelengths were read at $570 \mathrm{~nm}$ with a microplate spectrophotometer. The cell growth curve in each group was drawn according to the optical density values.

Bioinformatic predictions and luciferase assay. The prediction of the miR-194 target genes was performed using TargetScan version 3.1 (29). The results revealed that the 3'-UTR of Fbxw-7 is complementarily base paired with miR-194. In order to confirm the prediction, a luciferase assay was performed. Briefly, 293T cells were seeded $\left(1 \times 10^{4}\right.$ cells $\left./ \mathrm{ml}\right)$ in a 6 -well plate and incubated at room temperature for $24 \mathrm{~h}$. Subsequently, the cells divided into 3 groups and co-transfected with PGL3-Fbxw-7 3'UTR, miR-194 or an NC mimic using Lipofectamine ${ }^{\circledR} 2000$. Following $40 \mathrm{~h}$, the medium in each well was discarded and $500 \mu \mathrm{l}$ cell lysis solution was added. Following lysis, the supernatant was centrifuged at $15,000 \times \mathrm{g}$ for $5 \mathrm{~min}$ at room temperature. A total of $100 \mu 1$ luciferase assay reagent (Promega Corporation, Madison, WI, USA) was added into $100 \mu \mathrm{l}$ supernatant from each well. The relative intensity of fluorescence was determined using a multifunctional microplate reader (Tecan Group, Ltd., Mannedorf, Switzerland) with $2 \mathrm{sec}$ measurement intervals at an absorbance wavelength of $366 \mathrm{~nm}$ and $10 \mathrm{sec}$ measurement duration.

Statistical analysis. All data were analyzed using SPSS 16.0 (SPSS, Inc., Chicago, IL, USA). Data are presented as the mean \pm standard deviation. The miR-194 expression levels and MTT data were statistically analyzed using a two-tailed Student's t-test. $\mathrm{P}<0.05$ was considered to indicate a statistically significant difference.

\section{Results}

miR-194 expression associated with the differentiation degree of breast cancer. In order to explore the association between miR-194 expression levels and breast cancer, total RNA was extracted from the sera of 20 healthy adults, 26 patients with well differentiated breast cancer and 17 patients with poorly differentiated breast cancer. The results indicated that the serum expression levels of miR-194 were significantly higher in the well differentiated group $(\mathrm{P}<0.05$; Fig. 1$)$ and the poorly differentiated group ( $\mathrm{P}<0.05$; Fig. 1), as compared with in the control group. Additionally, the serum expression level of miR-194 was significantly higher in the poorly differentiated group, as compared with in the well differentiated group $(\mathrm{P}<0.01$; Fig. 1). Therefore, the serum expression level of miR-194 was closely associated with the differentiation degree of breast cancer, suggesting that miR-194 may be involved in the progression of breast cancer.

miR-194 expression enhances the proliferation of breast cancer cells. In order to determine the effect of miR-194 expression on breast cancer cell proliferation, MCF-7 and MDA-MB-231 breast cancer cell lines were transfected with the control, miR-194, antagomiR-194 or miR-194/antagomir-194. Following a 48-h transfection, the cells from the various groups were seeded into a 96-well plate in triplicate, and then cultured for $24 \mathrm{~h}$. Subsequently, an MTT assay was performed

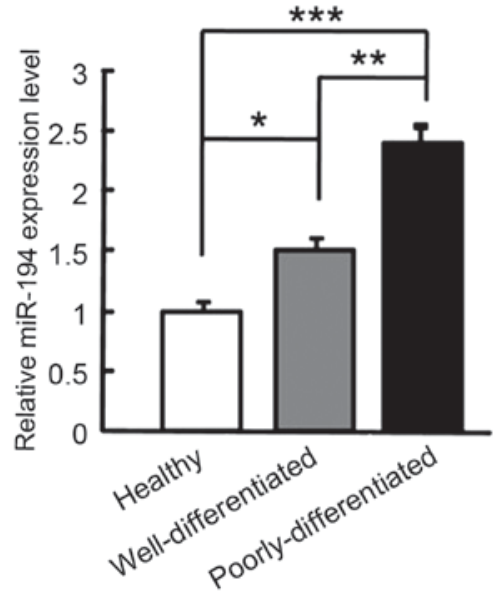

Figure 1. Relative expression levels of miR-194 in healthy adults and patients with well-differentiated and poorly differentiated breast cancer. The serum expression levels of miR-194 significantly increased in patients with well differentiated and poorly differentiated breast cancer, compared with in healthy adults. The serum expression level of miR-194 is significantly increased in patients with poorly differentiated breast cancer compared with in patients with well differentiated breast cancer. ${ }^{*} \mathrm{P}<0.05 ;{ }^{* *} \mathrm{P}<0.01$; ${ }^{* * * *} \mathrm{P}<0.005$. miR, microRNA.

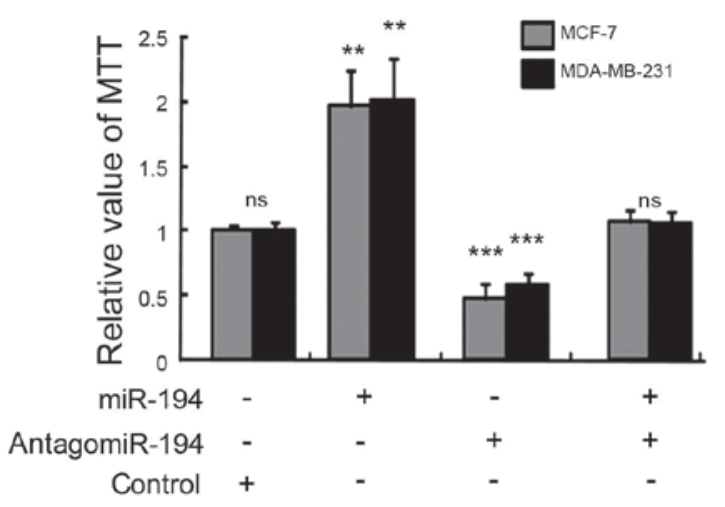

Figure 2. miR-194 promotes the proliferation of breast cancer cells. The proliferation rate was determined by an MTT assay. The overexpression of miR-194 significantly increased the proliferation of MCF-7 (grey bars) and MDA-MB-231 cells (black bars) compared with the mimic control only groups, respectively. ${ }^{* *} \mathrm{P}<0.01,{ }^{* * *} \mathrm{P}<0.005$ vs. miR-194 mimic control. miR, microRNA; antagomiR-194; antagonist microRNA; ns, not significant.

in order to determine the proliferation rate of breast cancer cells in the various groups. The results demonstrated that the overexpression of miR-194 significantly enhanced the proliferation of MCF-7 (P<0.01; Fig. 2) and MDA-MB-231 cells ( $\mathrm{P}<0.01$; Fig. 2). Additionally, the inhibition of miR-194 expression significantly decreased the proliferation of MCF-7 ( $\mathrm{P}<0.005$; Fig. 2) and MDA-MB-231 cells ( $<<0.005$; Fig. 2). No significant change was observed in the proliferation of cells co-transfected with miR-194 and antagomiR-194 (Fig. 2).

miR-194 may directly target its downstream gene, Fbxw-7, in breast cancer cells. According to the bioinformatic database (Targetscan) analysis and a previous study (30), Fbxw-7 may be a potential target of miR194. The binding sites for miR-194 were detected in the 3'-UTR of Fbxw-7, and were highly conserved and consistent between rats, mice and humans (Fig. 3A). Subsequently, the present study performed 
A

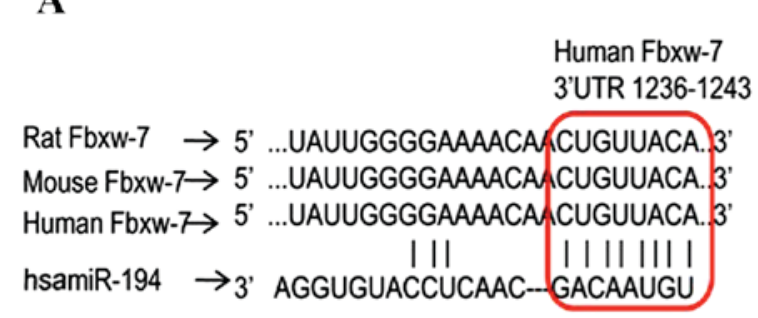

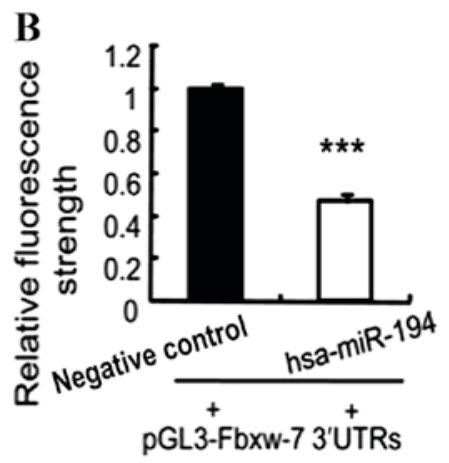

Figure 3. Fbxw-7 is a direct target gene of miR-194. (A) Bioinformatic prediction of the binding site of miR-194 in Fbxw-7 mRNA-3'UTR (using Targetscan). The red box indicates the 8 bp matched region between miR-194 and $F b x w$-7. Before the red box, they also share a 3 bp matched sub-region. (B) A luciferase reporter assay was performed in order to verify the prediction. The relative intensity of fluorescence was significantly inhibited in breast cancer cells transfected with miR-194 and PGL3-Fbxw-7 3'-UTR compared with in breast cancer cells transfected with miR-194 and the NC mimic. ${ }^{* * * *} \mathrm{P}<0.005$. NC, negative control; UTR, untranslated region; Fbxw-7, F-box/WD repeat-containing protein 7; miR, microRNA.

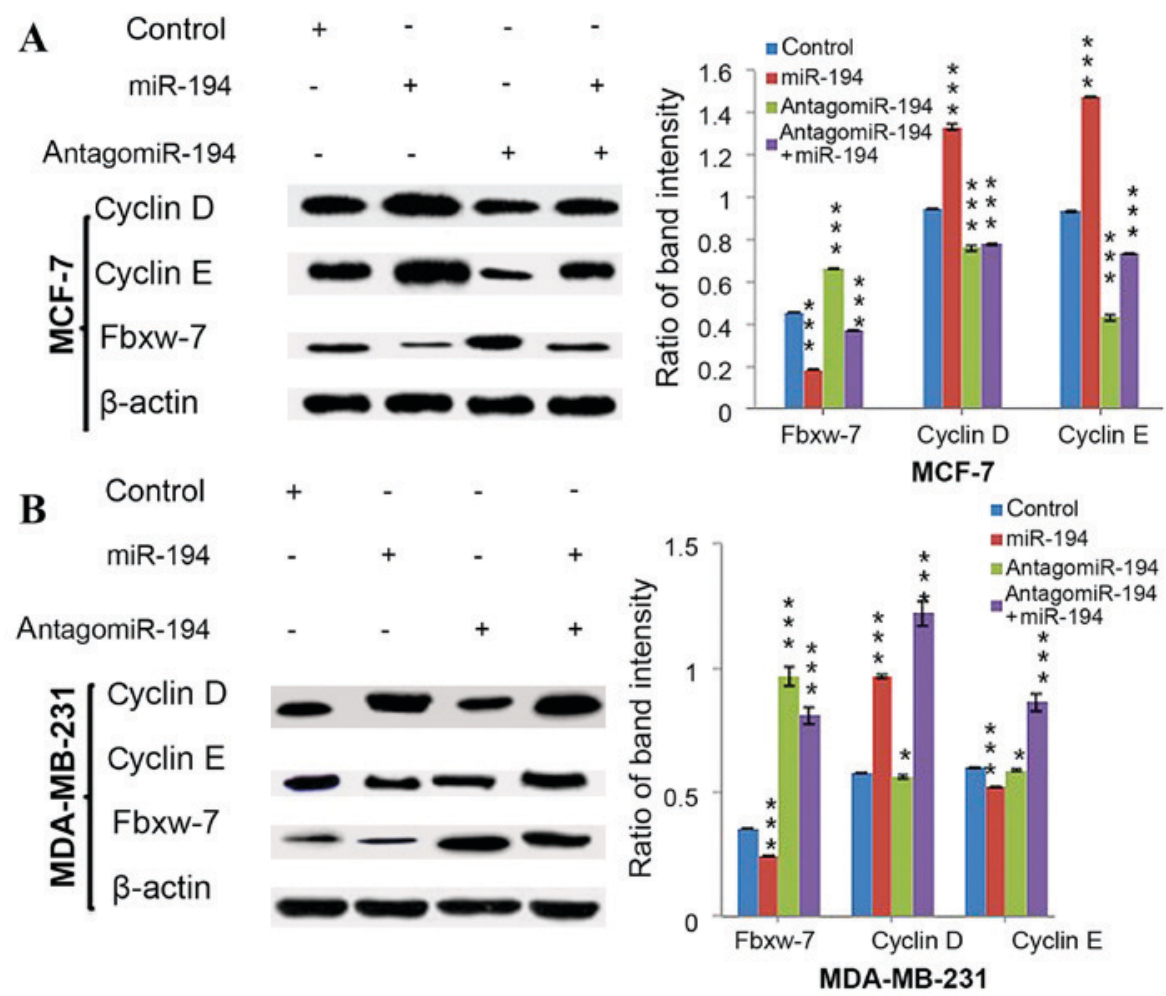

Figure 4. Western blot analysis of $F b x w-7$, cyclin D and cyclin $\mathrm{E}$ in transfected cells. Overexpression of miR-194 may downregulate the protein expression level of Fbxw-7 and upregulate the protein expression levels of cyclin D and cyclin E in (A) MCF-7 and (B) MDA-MB-231 cells compared with the control only group. The opposite results appeared in breast cancer cells transfected with antogomiR-194. ${ }^{*} \mathrm{P}<0.05 ;{ }^{* * *} \mathrm{P}<0.005$ vs. miR-194 mimic control. Fbxw-7, F-box/WD repeat-containing protein 7; miR, microRNA, antagomiR, antagonist microRNA.

a luciferase assay to confirm the prediction made using the results of the Targetscan analysis. The assay results revealed that luciferase activity was significantly reduced in breast cancer cells with overexpressed miR-194, compared with in the control cells, following transfection of PGL3-Fbxw-7 3'UTRs ( $\mathrm{P}<0.005$; Fig. 3B).

miR-194 promotes the expression levels of cyclin D and cyclin $E$ and inhibits the expression level of Fbxw-7. It has previously been reported that the inhibition of $F b x w-7$ may increase cell proliferation by increasing the number of ESCC cells in the S phase and decreasing the number of ESCC cells in the $\mathrm{G}_{1} / \mathrm{G}_{0}$ phase (31). The present study performed western blot analysis in order to determine the expression levels of the cyclin proteins, cyclin D and cyclin E. The results revealed that miR-194 expression inhibited the expression of $F b x w-7$, which additionally significantly increased the expression levels of cyclin D and cyclin E in MCF-7 ( $\mathrm{P}<0.05$, Fig. 4A) and MDA-MB-231 cells ( $\mathrm{P}<0.05$, Fig. 4B).

\section{Discussion}

Previous studies demonstrated that various expression levels of miRNA have been identified in cancer tissues $(6,32)$. miRNA 
may have clinical applications for use as a targeted therapy or for molecular diagnosis and prognosis $(5,7)$. The regulatory mechanisms underlying miRNA function in breast cancer have previously been studied (4,33-35).

miR-194 was first identified as a suppressor gene in the hepatic epithelial cells of mice by inhibiting the metastasis of liver cancer cells (36). In addition, in cancer of the gut $(37,38)$ and kidney (39), miR-194 served a similar inhibitory role. By contrast, it was suggested that miR-194 served a role in the promotion and progression of breast cancer (9) and pancreatic ductal adenocarcinoma (40). These studies indicated that miR-194 had various target genes (31-40). Previous studies have demonstrated that miR-194 inhibited cell migration and invasion, which may have contributed to the anti-tumor activity of trastuzumab on HER2-overexpressing breast cancer cells $(41,42)$. Iizuka et al (9) demonstrated that the expression level of miR-194 was increased in human breast cancer cell lines and a rat mammary cancer model induced by radiation. However, the downstream pathways of miR-194 in breast cancer are not currently known. Therefore, it is important to investigate its specific target genes in breast cancer in order to understand the regulatory mechanisms underlying miR-194.

In the present study, it was demonstrated that the E3 ubiquitin ligase $\mathrm{Fbxw}-7$ was the target gene for miR-194 in breast cancer. The results of the bioinformatic prediction analysis revealed that miR-194 had 367 potential target genes, which may be associated with the numerous functions of miR-194 in a variety of cancer subtypes. According to the ranking results of the bioinformatic analysis and previous studies investigating breast cancer cell proliferation $(41,42)$, the present study focused on the target gene of miR-194, $F b x w-7$, which was identified by performing a luciferase assay. Furthermore, the present study demonstrated that miR-194 promoted the proliferation of breast cancer cells by targeting Fbxw-7 and upregulating the expression levels of cyclins D and E. Previous studies revealed that $F b x w-7$ acted as a tumor suppressor gene in a number of cancer subtypes $(16,43)$. The mutation or deletion of $F b x w-7$ may induce the accumulation of cancer proliferation genes, including cyclin E, c-Myc and aurora kinase A (10). A previous study revealed that the expression level of $F b x w-7$ was significantly reduced in colorectal cancer tissues compared with in normal tissues, and the inhibition of $F b x w-7$ increased the proliferation of colorectal cancer cells (37). These results are similar to those of the present study. However, the expression level of miR-194 in the sera of patients with breast cancer of various differentiation grades was determined in the present study, and it was revealed that miR-194 expression is closely associated with the grade of breast cancer. The serum expression level of miR-194 was highest in patients with poorly differentiated breast cancer, which suggested that miR-194 may be a promising prognostic factor for breast cancer. In the present study, the inhibition of miR-194 expression by antagomiR-194 decreased the proliferation of breast cancer cells, which suggested that antagomiR-194 may be a potential therapeutic drug.

In conclusion, the present study indicated that miR-194 served an important role in the proliferation of breast cancer cells by directly inhibiting the expression of $\mathrm{Fbxw}-7$ and regulating the cell cycle. As a result, miR-194 may be a potential therapeutic target for inhibiting the progression of breast cancer. Therefore, it is necessary for future studies to verify the clinical values of miR-194 and determine the effects of antagomiR-194 as a treatment for breast cancer.

\section{References}

1. Van Diest PJ, van der Wall E and Baak JP: Prognostic value of proliferation in invasive breast cancer: A review. J Clin Pathol 57: 675-681, 2004.

2. Yu H, Yang J,Jiao S,Li Y,LiLand Wang J: A proliferation-inducing ligand expression in breast cancer and its relationship with prognosis. Nan Fang Yi Ke Da Xue Xue Bao 35: 185-190, 2015 (In Chinese).

3. Wu X, Zeng R, Wu S, Zhong J, Yang L and Xu J: Comprehensive expression analysis of miRNA in breast cancer at the miRNA and isomiR levels. Gene 557: 195-200, 2015.

4. Xue J, Chi Y, Chen Y, Huang S, Ye X, Niu J, Wang W, Pfeffer LM, Shao ZM, Wu ZH and Wu J: MiRNA-621 sensitizes breast cancer to chemotherapy by suppressing FBXO11 and enhancing p53 activity. Oncogene 35: 448-458, 2016.

5. Zaleska K: miRNA - Therapeutic tool in breast cancer? Where are we now? Rep Pract Oncol Radiother 20: 79-86, 2014.

6. Fiannaca A, La Rosa M, La Paglia L, Rizzo R and Urso A: Analysis of miRNA expression profiles in breast cancer using biclustering. BMC Bioinformatics 16 (Suppl 4): S7, 2015.

7. McGuire A, Brown JA and Kerin MJ: Metastatic breast cancer: The potential of miRNA for diagnosis and treatment monitoring. Cancer Metastasis Rev 34: 145-155, 2015.

8. Le XF, Almeida MI, Mao W, Spizzo R, Rossi S, Nicoloso MS, Zhang S, Wu Y, Calin GA and Bast RC Jr: Modulation of MicroRNA-194 and cell migration by HER2-targeting trastuzumab in breast cancer. PLoS One 7: e41170, 2012.

9. Iizuka D, Imaoka T, Nishimura M, Kawai H, Suzuki F and Shimada Y: Aberrant microRNA expression in radiation-induced rat mammary cancer: The potential role of miR-194 overexpression in cancer cell proliferation. Radiat Res 179: 151-159, 2013.

10. Fujii Y, Yada M, Nishiyama M, Kamura T, Takahashi H, Tsunematsu R, Susaki E, Nakagawa T, Matsumoto A and Nakayama KI: Fbxw7 contributes to tumor suppression by targeting multiple proteins for ubiquitin-dependent degradation. Cancer Sci 97: 729-736, 2006.

11. Koepp DM, Schaefer LK, Ye X, Keyomarsi K, Chu C, Harper JW and Elledge SJ: Phosphorylation-dependent ubiquitination of cyclin E by the SCFFbw7 ubiquitin ligase. Science 294: 173-177, 2001.

12. Moberg KH, Bell DW, Wahrer DC, Haber DA and Hariharan IK: Archipelago regulates Cyclin E levels in Drosophila and is mutated in human cancer cell lines. Nature 413: 311-316, 2001.

13. Strohmaier H, Spruck CH, Kaiser P, Won KA, Sangfelt O and Reed SI: Human F-box protein hCdc4 targets cyclin E for proteolysis and is mutated in a breast cancer cell line. Nature 413: 316-322, 2001.

14. Welcker M, Orian A, Jin J, Grim JE, Harper JW, Eisenman RN and Clurman BE: The Fbw7 tumor suppressor regulates glycogen synthase kinase 3 phosphorylation-dependent c-Myc protein degradation. Proc Natl Acad Sci USA 101: 9085-9090, 2004.

15. Yada M, Hatakeyama S, Kamura $T$, Nishiyama $M$, Tsunematsu R, Imaki H, Ishida N, Okumura F, Nakayama K and Nakayama KI: Phosphorylation-dependent degradation of c-Myc is mediated by the F-box protein Fbw7. EMBO J 23: 2116-2125, 2004.

16. Mao JH, Perez-Losada J, Wu D, Delrosario R, Tsunematsu R, Nakayama KI, Brown K, Bryson S and Balmain A: Fbxw7/Cdc4 is a p53-dependent, haploinsufficient tumour suppressor gene. Nature 432: 775-779, 2004.

17. Hubbard EJ, Wu G, Kitajewski J and Greenwald I: sel-10, a negative regulator of lin-12 activity in Caenorhabditis elegans, encodes a member of the CDC4 family of proteins. Genes Dev 11: 3182-3193, 1997.

18. Gupta-Rossi N, Le Bail O, Gonen H, Brou C, Logeat F, Six E, Ciechanover A and Israël A: Functional interaction between SEL-10, an F-box protein, and the nuclear form of activated Notch1 receptor. J Biol Chem 276: 34371-34378, 2001.

19. Oberg C, Li J, Pauley A, Wolf E, Gurney M and Lendahl U: The Notch intracellular domain is ubiquitinated and negatively regulated by the mammalian Sel-10 homolog. J Biol Chem 276: 35847-35853, 2001. 
20. Wu G, Lyapina S, Das I, Li J, Gurney M, Pauley A, Chui I, Deshaies RJ and Kitajewski J: SEL-10 is an inhibitor of notch signaling that targets notch for ubiquitin-mediated protein degradation. Mol Cell Biol 21: 7403-7415, 2001.

21. Nateri AS, Riera-Sans L, Da Costa C and Behrens A: The ubiquitin ligase SCFFbw7 antagonizes apoptotic JNK signaling. Science 303: 1374-1378, 2004.

22. Balamurugan K, Wang JM, Tsai HH, Sharan S, Anver M, Leighty $\mathrm{R}$ and Sterneck E: The tumour suppressor C/EBPd inhibits FBXW7 expression and promotes mammary tumour metastasis. EMBO J 29: 4106-4117, 2010.

23. Fu L, Balasubramanian M, Shan J, Dudenhausen EE and Kilberg MS: Auto-activation of c-JUN gene by amino acid deprivation of hepatocellular carcinoma cells reveals a novel c-JUN-mediated signaling pathway. J Biol Chem 286: 36724-36738, 2011.

24. Snijders AM, Liu Y, Su L, Huang Y and Mao JH: Expression profiling reveals transcriptional regulation by Fbxw7/mTOR pathway in radiation-induced mouse thymic lymphomas. Oncotarget 6: 44794-44805, 2015.

25. Hernandez MA, Patel B, Hey F, Giblett S, Davis H and Pritchard C: Regulation of BRAF protein stability by a negative feedback loop involving the MEK-ERK pathway but not the FBXW7 tumour suppressor. Cell Signal 28: 561-571, 2016.

26. Akhoondi S, Lindström L, Widschwendter M, Corcoran M, Bergh J, Spruck C, Grandér D and Sangfelt O: Inactivation of FBXW7/hCDC4- $\beta$ expression by promoter hypermethylation is associated with favorable prognosis in primary breast cancer. Breast Cancer Res 12: R105, 2010.

27. Li J, Guo Y, Liang X, Sun M, Wang G, De W and Wu W: MicroRNA-223 functions as an oncogene in human gastric cancer by targeting FBXW7/hCdc4. J Cancer Res Clin Oncol 138: 763-774, 2012.

28. Livak KJ and Schmittgen TD: Analysis of relative gene expression data using real-time quantitative PCR and the 2(-Delta Delta C(T)) method. Methods 25: 402-408, 2001.

29. Lewis BP, Shih, I-h Jones-Rhoades MW, Bartel DP and Burge CB: Prediction of mammalian microRNA targets. Cell 115: 787-798, 2003

30. Chen $P$ and Yao GD: The role of cullin proteins in gastric cancer. Tumor Biol 37: 29-37, 2016.

31. Wu XZ, Wang KP, Song HJ, Xia JH, Jiang Y and Wang YL: MiR-27a-3p promotes esophageal cancer cell proliferation via F-box and WD repeat domain-containing 7 (FBXW7) suppression. Int J Clin Exp Med 8: 15556-15562, 2015.

32. Liu SG, Qin XG, Zhao BS, Qi B, Yao WJ, Wang TY, Li HC and $\mathrm{Wu} X \mathrm{X}$ : Differential expression of miRNAs in esophageal cancer tissue. Oncol Lett 5: 1639-1642, 2013.
33. Tanić M, Yanowski K, Andrés E, Gómez-López G, Socorro MR, Pisano DG, Martinez-Delgado B and Benítez J: miRNA expression profiling of formalin-fixed paraffin-embedded (FFPE) hereditary breast tumors. Genom Data 3: 75-79, 2014.

34. Hu J, Xu J, Wu Y, Chen Q, Zheng W, Lu X, Zhou C and Jiao D: Identification of microRNA-93 as a functional dysregulated miRNA in triple-negative breast cancer. Tumour Biol 36: 251-258, 2015.

35. Wu Z, Wang P, Song C, Wang K, Yan R, Li J and Dai L: Evaluation of miRNA-binding-site SNPs of MRE11A, NBS1, RAD51 and RAD52 involved in HRR pathway genes and risk of breast cancer in China. Mol Genet Genomics 290: 1141-1153, 2015.

36. Zhang W, Qian P, Zhang X, Zhang M, Wang H, Wu M, Kong X, Tan S, Ding K, Perry JK, et al: Autocrine/paracrine human growth hormone-stimulated MicroRNA 96-182-183 cluster promotes epithelial-mesenchymal transition and invasion in breast cancer. J Biol Chem 290: 13812-13829, 2015.

37. Meng Z, Fu X, Chen X, Zeng S, Tian Y, Jove R, Xu R and Huang W: miR-194 is a marker of hepatic epithelial cells and suppresses metastasis of liver cancer cells in mice. Hepatology 52: 2148-2157, 2010

38. Song Y, Zhao F, Wang Z, Liu Z, Chiang Y, Xu Y, Gao P and $\mathrm{Xu} \mathrm{H}$ : Inverse association between miR-194 expression and tumor invasion in gastric cancer. Ann Surg Oncol 19 (Suppl 3): S509-S517, 2012

39. Chen X, Wang Y, Zang W, Du Y, Li M and Zhao G: miR-194 targets RBX1 gene to modulate proliferation and migration of gastric cancer cells. Tumour Biol 36: 2393-2401, 2015.

40. Khella HW, Bakhet M, Allo G, Jewett MA, Girgis AH, Latif A, Girgis H, Von Both I, Bjarnason GA and Yousef GM: miR-192, miR-194 and miR-215: A convergent microRNA network suppressing tumor progression in renal cell carcinoma. Carcinogenesis 34: 2231-2239, 2013.

41. Zhang J, Zhao CY, Zhang SH, Yu DH, Chen Y, Liu QH, Shi M, Ni CR and Zhu MH: Upregulation of miR-194 contributes to tumor growth and progression in pancreatic ductal adenocarcinoma. Oncol Rep 31: 1157-1164, 2014.

42. Yokobori T, Mimori K, Iwatsuki M, Ishii H, Onoyama I, Fukagawa T, Kuwano H, Nakayama KI and Mori M: p53-Altered FBXW7 expression determines poor prognosis in gastric cancer cases. Cancer Res 69: 3788-3794, 2009.

43. Iwatsuki M, Mimori K, Ishii H, Yokobori $T$, Takatsuno Y, Sato T, Toh H, Onoyama I, Nakayama KI, Baba H and Mori M: Loss of FBXW7, a cell cycle regulating gene, in colorectal cancer: Clinical significance. Int J Cancer 126: 1828-1837, 2010. 